Brit. J. industr. Med., 1962, 19, 216.

\title{
EFFECT OF TETRAETHYL THIURAM DISULPHIDE (DISULFIRAM) ON METABOLISM OF TRICHLORO- ETHYLENE IN MAN
}

\author{
BY \\ V. BARTONÍČEK and J. TEISINGER \\ From the Institute of Industrial Hygiene and Occupational Diseases, Prague
}

(RECEIVED FOR PUBLICATION DECEMBER 21, 1961)

\begin{abstract}
The amounts of trichloroethanol and trichloroacetic acid excreted in the urine of four subjects who inhaled trichloroethylene in a concentration of about $1 \mathrm{mg}$./l. for a period of five hours in a laboratory experiment were determined. This experiment was repeated under the same conditions after tetraethyl thiuram disulphide (disulfiram) had been given in divided doses, totalling 3 or $3.5 \mathrm{~g}$. The elimination of trichloroethanol in urine was decreased by 40 to $64 \%$, and of trichloroacetic acid by 72 to $87 \%$. The trichloroethylene excreted by the lungs in two of the subjects increased up to $65 \%$ of that retained within five hours. It is concluded that tetraethyl thiuram disulphide (disulfiram) strikingly inhibits the oxidation of trichloroethylene.

The possible therapeutic use of this substance in cases of severe peroral trichloroethylene intoxication is discussed.
\end{abstract}

In considering the toxicity of trichloroethylene (TRI) it is necessary to bear in mind the effect both of the whole molecule and that of its main metabolite trichloroethanol (TCE). Since TRI itself is very rapidly eliminated from the organism through the lungs we believe that the protracted narcotic effect of TRI is due to the TCE which is formed and which is eliminated rather slowly. This belief is supported by clinical observations of acute intoxication (Přerovská, Srbová, and Stýblová, 1958). The conversion of TRI to TCE cannot therefore be considered as detoxication since the metabolite is more toxic (Souček and Vlachová, 1960; Mikisková and Mikiska, 1960). TCE probably only loses its narcotic properties after conjugation with glucuronic acid (Butler, 1949a). The next metabolite, trichloroacetic acid (TCA), described for the first time in dog urine by Barrett and Johnston (1939), can be considered non-toxic in the amount eliminated during intoxication with TRI. Theoretically the production of chloral, which was assumed by Butler (1949a), should be taken into consideration, but this has not been convincingly substantiated up to the present. Scansetti, Rubino, and Trompeo (1959) have recently described its presence in the human organism, but the methods used and the interpretation of results cannot, in our opinion, be accepted without reserve. In recent years Souček and Vlachová have described other metabolites, namely monochloro-acetic acid (1954) and chloroform (1955). The production of these substances has not been confirmed by other authors.

In the belief that TCE is the toxic metabolite of TRI, one of us (Bartoníček, 1962) tried to influence the oxidation of TRI into TCE. In laboratory experiments on man he showed that sodium lactate and fructose, administered intravenously, significantly decreased the amount of TCE eliminated in urine; fructose also significantly increased the amount of TCA eliminated. Thus he suggested that these substances be administered in TRI intoxication.

Forssman, Owe-Larsson, and Skog (1955) reported that tetraethyl thiuram disulphide (disulfiram) greatly reduced the excretion of TCA in urine after the administration of TRI or TCE to rats. They considered that the metabolism of TRI takes the following course: TRI $\rightarrow$ TCE $\rightarrow$ trichloroacetaldehyde (chloral) $\rightarrow$ TCA. They ascribed the effect of disulfiram to a suppression of the oxidation of chloral. Others have previously described the inhibitory effect of disulfiram on aldehyde oxidase, mainly in liver. Bardoděj, Krivucová, and Pokorný (1955) treated two dogs, weighing $10 \mathrm{~kg}$., with $0.2 \mathrm{~g} . / \mathrm{kg}$. of disulfiram and the following day they 
exposed them to TRI at a concentration of $25 \mathrm{mg} . / 1$. of air for 40 minutes. Shortly after the narcosis the animals showed restlessness, tremor, and cramps. Dogs exposed to TRI but not given disulfiram had no such sequelae. The authors concluded that disulfiram increased the toxicity of TRI. According to Kjeldgaard (1948) the S-S grouping of tetraethyl thiuram disulphide is mainly responsible for this reaction. Butler (1949b), on the other hand, is of the opinion that the metabolism of TRI in the dog takes the following path:

TRI $\longrightarrow$ chloral $\coprod_{\text {TCA }}$ TCE . Souček and Vlachová

(1955), on the basis of their experiments, suggested the following scheme:

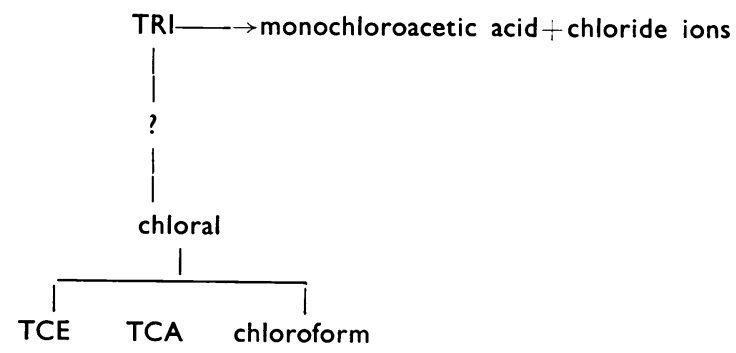

Because Forssman et al. (1955) did not measure the excretion of TCE, and since the metabolism of TRI in animals differs from that in man, we have tried to verify the effect of disulfiram in man exposed to TRI vapours.

\section{Methods}

The experiment was carried out on four healthy women volunteers, between the ages of 21 and 36 . These subjects while at rest underwent a single exposure in the gas chamber for five hours at a TRI concentration of about $1 \mathrm{mg}$./l. During exposure the concentration of TRI was regularly controlled.

Air samples were taken by an igelite tube into an evacuated glass cylinder of $0 \cdot 3$ to 0.51 . volume after removal of the dead space in the tube. The cylinder was kept in a refrigerator at $0^{\circ} \mathrm{C}$., and $10 \mathrm{ml}$. of cooled pyridine was added. After five minutes shaking in the electric shaker TRI was determined by the method of Souček and Franková (1952). The measuring estimations were carried out on a spectrophotometer Kautsky at $4250 \AA$. The calibration curve was linear.

The samples of expired air were obtained during the period in the chamber by making the subject expire through a broad igelite tube into the mixing flask (101. volume) which was placed outside the chamber, for exactly five minutes. The air from the flask was passed through the gas meter which measured air intake per minute. From the mixing flask 0.3 to 0.51 . of air was taken for analysis. After leaving the chamber the two subjects expired air freely into a glass cylinder and the expired air was analysed as described above. In the determination of TRI in the expired air $\mathrm{CO}_{2}$ may have an effect by shifting the $p \mathrm{H}$ of the reacting components of the solution to the acid side (Bardoděj and Krivucová, 1956). Since both the present series of experiments were carried out on the same subjects and under the same conditions, we consider any such effect insignificant.

In two subjects (Z.H. and D.V.) 24-hour urine samples were collected for 16 days, in the other two (V.F. and H.D.) for 21 days. TCE in urine was determined colorimetrically according to the method of Vlachova (1957), and TCA was determined according to the method of Souček and Franková (1952). The calibration curves were linear, and the measurements were carried out on the spectrophotometer Kautsky at $5100 \AA$.

Each of the four subjects was exposed twice within a period of eight months. The first time they received nothing, but during the second period they were given disulfiram in 0.5 g. tablets. Subjects V.F. and H.D. were given $0.5 \mathrm{~g}$. twice daily one day before the exposure, on the day of exposure, and on the following day. The subjects Z.H. and D.V. received the same dose two days before exposure and on the day of exposure and in the morning after exposure they received a further $0.5 \mathrm{~g}$.

During the period of the experiment the subjects recorded details of their meals and any unusual events.

\section{Results}

In all four experimental subjects the administration of disulfiram significantly decreased the elimination of TCA and a considerable decrease of TCE in urine was also observed. Fig. 1 shows the elimination of TCE and TCA after TRI inhalation when no disulfiram was given to subject V.F. and in the same subject after the administration of $3 \mathrm{~g}$. of disulfiram. The retention of TRI in both experiments was practically the same $(1010$ and $1000 \mathrm{mg}$. in the five hours) the concentrations being $960 \mu \mathrm{g}$./l. and $1012 \mu \mathrm{g} . / 1$. respectively.

Fig. 2 shows the same arrangement of the experiment with D.V. who, in the first exposure to a concentration of $960 \mu \mathrm{g} . / \mathrm{l}$. for five hours, retained $1057 \mathrm{mg}$. of TRI, and who in the second exposure at a concentration $1010 \mu \mathrm{g}$./l., retained $1320 \mathrm{mg}$. of TRI. The disulfiram was administered at different times, and the total dose was $3.5 \mathrm{~g}$. In all cases there was a raising of the level of both metabolites after the action of disulfiram had ended. We assume that this arises from the fraction of TRI which is slowly released from the fat depots in the organism and then metabolized. It is probable that further administration of disulfiram after exposure would further decrease the metabolites excreted, as shown by elimination curves in the subjects Z.H. and D.V., where a greater dose of disulfiram resulted in a lower level of both metabolites in the urine.

In Table 1 the findings in the first and second 

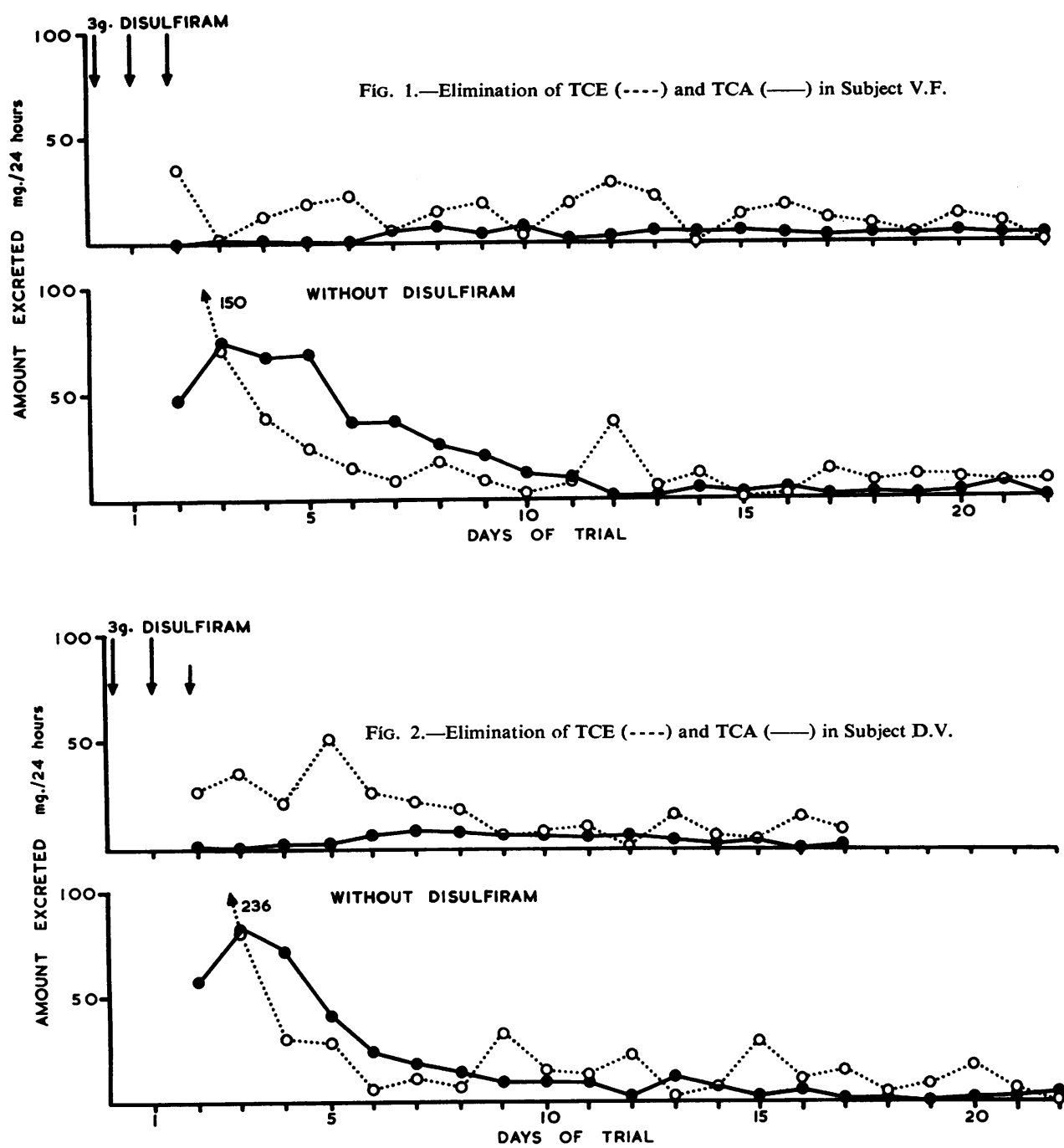

TABLE 1

QUANTITY OF TRI RETAINED AFTER A FIVE-HOUR EXPOSURE AND QUANTITIES OF TCE AND TCA EXCRETED BY HUMAN SUBJECTS WITH AND WITHOUT TREATMENT BY DISULFIRAM

\begin{tabular}{|c|c|c|c|c|c|}
\hline Subject & $\begin{array}{c}\text { Retained TRI } \\
\text { (mg.) }\end{array}$ & $\underset{\text { (g.) }}{\text { Substance Administered }}$ & $\underset{(\%)}{\text { TRI }} \underset{\text { Eliminated as TCE }}{\text { (\%) }}$ & $\underset{(\%)}{\underset{\text { TRI }}{\text { Eliminated as TCA }}}$ & $\begin{array}{l}\text { Total TRI } \\
\text { Eliminated as } \\
\text { TCE and TCA } \\
(\%)\end{array}$ \\
\hline $\begin{array}{l}\text { V.F. } \\
\text { v.F. } \\
\text { H.D. } \\
\text { H.D. } \\
\text { Z.H. } \\
\text { Z.H. } \\
\text { D.V. } \\
\text { D.V. }\end{array}$ & $\begin{array}{r}1010 \\
1000 \\
874 \\
910 \\
891 \\
1120 \\
1057 \\
1320\end{array}$ & $\begin{array}{l}\text { Disulfiram } \frac{\overline{3}}{\overline{3}} \\
\text { Disulfiram } \\
\text { Disulfiram } \frac{\overline{3}}{3 \cdot 5} \\
\text { Disulfiram } \frac{\overline{3 \cdot 5}}{}\end{array}$ & $\begin{array}{l}42 \cdot 6 \\
25 \cdot 5 \\
49 \cdot 7 \\
29 \cdot 2 \\
43 \cdot 9 \\
16 \cdot 0 \\
48.4 \\
18 \cdot 5\end{array}$ & $\begin{array}{r}35.7 \\
7.1 \\
27.4 \\
7.9 \\
29 \cdot 6 \\
5.3 \\
27.9 \\
3.8\end{array}$ & $\begin{array}{l}78 \cdot 3 \\
32 \cdot 6 \\
77 \cdot 1 \\
37 \cdot 1 \\
73 \cdot 5 \\
21 \cdot 3 \\
76 \cdot 3 \\
22 \cdot 3\end{array}$ \\
\hline $\begin{array}{l}\text { Average mean } \\
\text { Mean treated }\end{array}$ & $\begin{array}{r}958 \\
1087\end{array}$ & & $\begin{array}{l}46 \cdot 1 \\
22 \cdot 3\end{array}$ & $\begin{array}{r}30 \cdot 1 \\
6 \cdot 0\end{array}$ & $\begin{array}{l}76 \cdot 2 \\
28 \cdot 3\end{array}$ \\
\hline
\end{tabular}

Both metabolites in urine were estimated in V.F. and H.D. for a period of 21 days, and in Z.H. and D.V. for 16 days. 


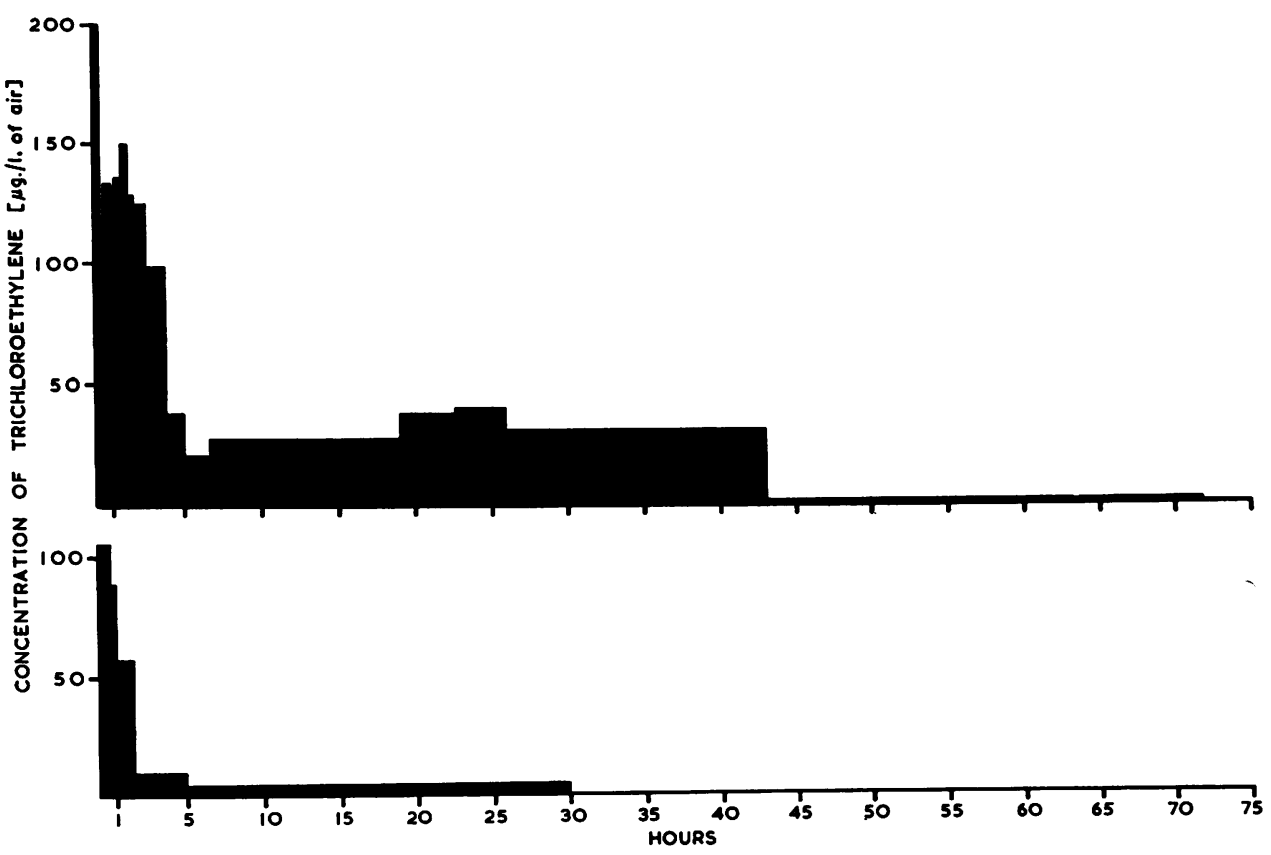

|Fíc. 3.-Elimination of TRI in expired air in Subject V.F. The upper part of the diagram is after administration of disulfiram.

series of exposures in the four subjects are compared. It is evident that in the first experiment the subjects excreted roughly the same percentage of TRI as TCE and TCA; the amount of TCE was greater. After the administration of disulfiram the amount of TCE excreted decreased in the subjects V.F. and H.D. by about $40 \%$, and in subjects Z.H. and D.V. by more than $60 \%$. The amount of TCA excreted fell by $80 \%, 71 \%, 82 \%$, and $87 \%$ respectively.

In two subjects (V.F. and H.D.) the quantitative determination of TRI in the expired air was carried out after the exposure until it fell to zero. The zero values were reached within 43 hours. V.F. retained $1000 \mathrm{mg}$., and H.D. $910 \mathrm{mg}$. of TRI during the five-hour exposure to a concentration of $1012 \mu \mathrm{g}$./l. Figs. 3 and 4 show the result of the investigation. In comparing the results with our previous experiments (Souček, Teisinger, and Pavelková, 1952), which showed that under normal circumstances the concentration of TRI decreases very rapidly within the first $\mathbf{3 0}$ minutes, it can be seen that after the administration of disulfiram a high concentration of TRI is maintained for four to five hours after the exposure has been completed.

The excretion of TRI through the lungs differs considerably in individuals and probably depends on the rate of TRI metabolism. In earlier experiments it amounted to $19 \%$ ( 4 to $43 \%$ ) of retained
TRI on the average. After the administration of disulfiram the subjects expired 64.5 or $65.4 \%$, which is considerably greater (Table 2 ).

In the subjects given disulfiram we did not observe any symptoms of intolerance to TRI such as were encountered in the investigations of Bardoděj et al. (1955). The doses of disulfiram given in these investigations were, however, so low that the results of both investigations cannot be compared.

\section{Discussion}

Forssman et al. (1955) showed that a considerable decrease in the elimination of TCA followed the administration of disulfiram to rats after exposure to TRI. Our findings show that disulfiram also has this effect in man and, moreover, we find that the elimination of TCE is much reduced. Since there is also a considerable increase of the TRI eliminated through the lungs, we assume that disulfiram suppresses the oxidation of TRI itself. If the effect of disulfiram is to suppress the action of enzymes, it would probably be an inhibition of the oxidases which oxidize TRI. It is probable that there occurs simultaneously an inhibitory effect on aldehyde dehydrogenases which convert chloral into TCA, because the elimination of TCA and presumably its production is very small and is less than the production of TCE. 
TABLE 2

BALANCE OF RETAINED AND EXCRETED TRI IN HUMAN SUBJECTS AFTER ADMINISTRATION OF DISULFIRAM

\begin{tabular}{|c|c|c|c|c|c|}
\hline \multirow{3}{*}{ Subject } & \multirow{3}{*}{$\begin{array}{c}\text { Amount of TRI Retained Within } \\
\text { Five Hours (mg.) }\end{array}$} & \multicolumn{3}{|c|}{ Amount of TRI Eliminated Within 21 Days } & \multirow{3}{*}{$\underset{(\%)}{\text { Total as }}$ TRI } \\
\hline & & \multirow{2}{*}{$\begin{array}{c}\text { In Expired Air } \\
\begin{array}{c}\text { Free } \\
(\%)\end{array}\end{array}$} & \multicolumn{2}{|c|}{ In Urine } & \\
\hline & & & In Form of TCE & In Form of TCA & \\
\hline $\begin{array}{l}\text { V.F. } \\
\text { H.D. }\end{array}$ & $\begin{array}{r}1000 \\
910\end{array}$ & $\begin{array}{l}65 \cdot 4 \\
64 \cdot 5\end{array}$ & $\begin{array}{l}25 \cdot 5 \\
29 \cdot 2\end{array}$ & $\begin{array}{l}7.1 \\
7.9\end{array}$ & $\begin{array}{r}98 \cdot 1 \\
101 \cdot 6\end{array}$ \\
\hline
\end{tabular}

This is in accord with the views of Butler (1949b) and Souček and Vlachová (1955) who believe that chloral is a precursor common to both TCE and TCA. If the assumption of Forssman et al. (1955) that metabolism of TRI passes via TCE and chloral to TCA were correct, decreased production of both metabolites simultaneously could not occur.

The therapeutic use of disulfiram in TRI poisoning seems possible because it would result in a greater part of the TRI being eliminated through the lungs within four to five hours. This would limit the production of the toxic TCE which may be very important in severe intoxication. This method has been used at the Clinic of Occupational Medicine in Prague, but experience with it is not yet adequate. In poisoning by inhalation disulfiram could only be considered in cases where it could be administered shortly after inhalation. Unfortunately, a preparation for injection is not yet available, so that disulfiram must be administered as a water suspension by stomach tube. In severe intoxication after swallowing TRI, where the stomach must be washed out in unconscious patients, the administration of disulfiram is simple. TRI is absorbed far more slowly from the alimentary tract, and in poisoning by this route it is more probable that disulfiram would exert its inhibitory action on the oxidative enzymes of TRI for several hours after the ingestion. The simultaneous administration of oleum paraffini, in which TRI dissolves, but which is not absorbed, is a form of treatment of which we have experience. Prophylactic administration of disulfiram in persons working with TRI cannot be considered owing to the toxicity of disulfiram itself.

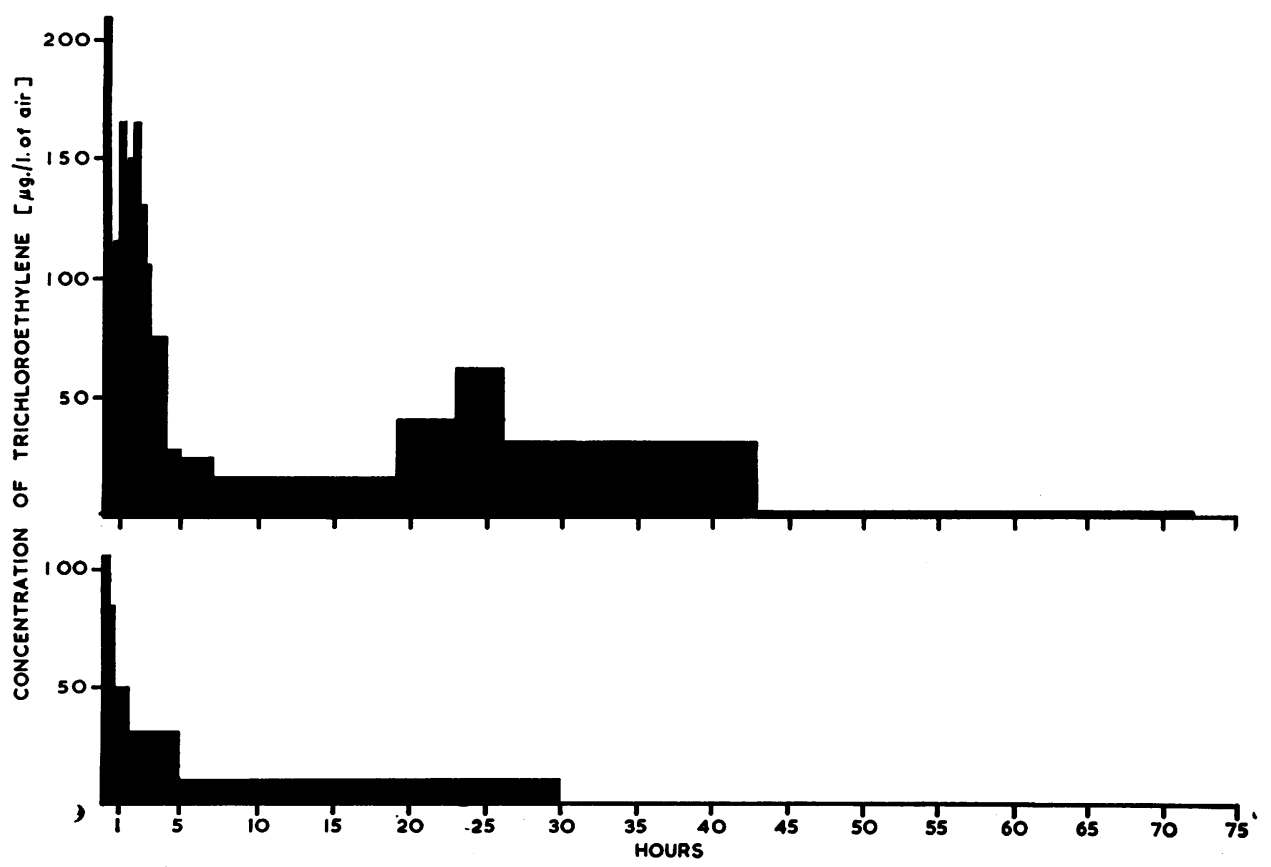

FíG. 4.-Elimination of TRI in expired air in subject H.D. The upper part of the diagram is after administration of disulfiram. 


\section{REFERENCES}

Bardoděj, Z., and Krivucová, M. (1956). Pracov. Lék., 8, 186. $\overline{-}, \frac{\mathrm{J}}{\mathrm{H}}$, and Pokorný, F. (1955). ibid., 7, 263.

Barrett, H. M., and Johnston, J. H. (1939). J. biol. Chem., 127, 765. Bartonicek, V.,(1962). Arch. environm. Hith. In the press.

Butler, T. C. (1949a). Fed. Proc., 8, 278.

- (1949b). J. Pharmacol. exp. Ther. 97, 84.

Forssman, S., Owe-Larsson, A., and Skog, E. (1955). Arch. Gewerbepath. Gewerbehyg. 13, 619.

Kjeldgaard, N. O. (1948). Acta pharmacol. (Kbh.), 5, 397.
Mikisková, H., and Mikiska, A. (1960). Arch. Gewerbepath. Gewerbehyg., 18, 310.

Přerovská, I., Srbová, J., and Stýblová, V. (1958). Pracov. Lék., $10,417$.

Scansetti, G., Rubino, G. F., and Trompeo, G. (1959). Med. $d$. Lavoro, $50,743$.

Souček, B., and Franková, E. (1952). Pracov. Lék., 4, 264.

-, Teisinger, J., and Pavelková, E. (1952). ibid., 4, 31.

-, and Vlachová, D. (1954). ibid., 6, 330.

, (1955). ibid., 7, 143.

Vlachová (1960). Brit. J. industr. Med., 17, 60.

\section{THE APRIL (1962) ISSUE}

The April (1962) issue contains the following papers:-

Phosphorus Necrosis of the Jaw: A Present-day Study. J. P. W. Hughes, R. Baron, D. H. Buckland, M. A. Cooke, J. D. Craig, D. P. Duffield, A. W. Grosart, P. W. J. Parkes, and A. Porter

Investigation of an Outbreak of Photodermatitis Confined to One Shop in a Large Factory. D. W. Wynn Jones

Retirement Reconsidered. A Review. A. R. Emerson

Sickness Absence in Teachers. John Simpson

Sickness Absence in the Three Principal Ethnic Divisions of Singapore. C. P. Collins

Carcinoma of the Skin in Machine Tool Setters. J. G. Fife

Byssinosis in the Cotton Industry of Egypt. Mostafa A. El Batawi

Serum Proteins and Serum Glycoproteins in the Differential Diagnosis of Silicosis and Silico-tuberculosis. H. Oyanguren, R. Silva, A. Rosenkranz, and J. Isa

Metabolism and Excretion of Trichloroethylene after Inhalation by Human Subjects. V. Bartoníček

Obituary

Book Reviews

A number of copies are still available and may be obtained from the Publishing Manager, British Medical Association, Tavistock Square, W.C.1, price 17s. $6 d$. 